\title{
Trends and Food Technology Gap in Global Food Policy
}

\author{
Hadi Akbar Dahlan \\ Department of Biotechnology, Graduate School of Engineering, Osaka University, 2-1 \\ Yamadaoka, Suita, Osaka 565-0871, Japan \\ Corresponding email: hadiakbar1591@ rocketmail.com
}

\begin{abstract}
This paper presents an argument to call for more focus in food technology innovation in food policy. Failed food policy had bring devastated results. Some examples of failed food policy can be seen through three famine cases (Ireland, India and North Korea) discussed here that occurs throughout the $20^{\text {th }}$ century. However, there are some themes from the previous failed policy are still implemented in current food policy. The similar themes are green revolution, sustainable intensification, dependency on importation and nutritional well-being. This paper also discuss the need to emphasize the researches on available resources to create novel food products, which is a gap on various food policies.
\end{abstract}

Keywords: Food Policy, Food technology, policy gap, famine, food policy trends, food innovation. 


\section{Introduction}

Food policy is a principle guide to the operation of the food and agriculture system. The term was first used officially during the first meeting of World Food Council, and latter conventionalized through the establishment of the International Food Policy Research Institute (IFPRI) at 1975. However, the food policies at the time were simple objectives with no integrated planning (Timmer, Falcon, \& Pearson, 1981). There are early concepts of plans for food policy in the field of agriculture (Spedding, 1979) and nutrition (Levinson, 1974) but European Union's 1981 Plan of Action to Combat Hunger in the World that was the earliest to utilize food policies (Maxwell \& Slater, 2003).

However, there are significant changes in trends of past and present food policies. The food policies are turning from food supply oriented (agricultural technology and food production) to food demand oriented (economic and competition value-chain) (Maxwell \& Slater, 2003). The dependency to this route of economic activity does have weaknesses, where there will be economic manipulations (such as market power) that bring catastrophic result to the population. It had occurred in Malaysia just recently, where the food prices are determined by market power; the food price increases with rising oil price few years ago but does not decrease when the oil price lowered (Ibrahim, 2015). Economic manipulation was also one of the main causes in the famine that occur in India, Ireland and North Korea (Kinealy, 2001; Meena, 2015; Natsios, 1999). The downside of

the trend is notified and documented (Bohstedt, 2014; Headey, 2011; Robert Kenner, 
2008), but there was not much we can do since global market had already invested fully to this economic activity. There are calls for reforms and enactment of policy changes but the challenge was enormous and it is an ongoing fighting to this day (Robert Kenner, 2008).

This paper does not intend to criticize the economic trend of food policies as there are many papers that do so, but to suggest an improvisation of food policy to include an oftendisregard area which is food technology. It was mentioned numerously in various food policies, but the effort was often re-directed toward agriculture and market activity. This paper also intends to summarize the (mis)-effort of food policies during several famines and emphasize the gap in current trend of food policies.

\section{Failed Food Policies}

Failed food policies in this context are failed food operations that are unfair whether to the consumer or food market. This mismanagement or manipulation of food policies mainly occur due to provision politics. There are bound to be civil unrest wherever its occur such as the riots at Haiti and Egypt, back in 2008 (Bohstedt, 2014). Certain food riots manage to achieve its objective, however some do not. There are also population that conforms to the unfair food policies until the later stage of famine. The following are selected famine cases that are due to (direct and indirectly) unfair food policy.

Irish Famine of 1840's 
The most examined famine case is the Irish potato famine. This is because the famine cause the wave of Irish emigration to the United States (Leathers. \& Foster., 2010). At the time, poverty is widespread in Ireland. Under the rule of Great Britain, the Irish are mostly landless farmers working under landlord fields. Their main crop are potatoes which also serve as their main diet. However, potato blight (a fungus that makes potatoes rot) occurred and soon destroyed the whole crop of potatoes in Ireland.

Deprived of their main diet, the Irish were starved to death. To put salt into injury, the famine were aid by malnutrition problem such as Scurvy (Geber \& Murphy, 2012). The estimates of death toll were $20-30 \%$ of the whole Ireland's pre-famine population. Due to rising famine death toll, the British government did response with a policy. Their policy include importation of grain from United States, support for poor families, public works for the jobless, and setting up soup kitchens to affected areas (Leathers. \& Foster., 2010).

However, the cost of the programs was funded through tax collection on the landlords. To evade tax, the landlord simply evicted the poor, starved Irish landless laborer into the streets. On recent findings, there is evidence that not all agriculture land were affected with the potato blight. Fotheringham and colleagues (2013) conducted spatial variation test across Ireland to observe the population pressure on land. They found that the spatial variation of the land is uneven, meaning there are land that may had not been affected by the potato blight. They then cross reference with local population records during the famine and found that the population still decline even on lands that were not affected by 
the blight (Fotheringham et al., 2013). From this evidence, we can infer that the landlord were inhumane to evict even those who are able to support themselves.

Besides the poorly coordinated policy, the trade policy was never scrutinized and criticized at the time (Kinealy, 2001). The British government at the time was ardent follower of laissez faire or free trade. According to this dogma, the government should not intervene with the trading activity. As a result, food exports from Ireland still continued even during the famine. Foods that were supposed to be used to feed the workers were sold to merchants for profits (Kinealy, 2001). There were apothecaries and volunteers that came to Ireland with the aim to relieve the families from malnutrition and famine. But this effort failed due to relief commissioner and scientific board bureaucracy and lack of judgment in coordinating fund and food allocation (Ian, 2013). To quote Kinealy (2001) notes: "The Irish poor did not starve because there was an inadequate supply of food within the country; they starved because political, commercial and individual greed was given priority over saving of lives".

India's era of severe famine (1876-1879 and 1896-1902)

Following Bengal famine of the 1770, the British colonial government still maintained its burden taxation system to the farmers of India during the great famine of 1876-79. During the time, almost everything was taxed; from agricultural products to even cow dung fertilizers. This leaves the farmers with nothing left to feed them. As millions of Indians starves to death, the exportation of rice and wheat still continues (Meena, 2015). 
There were attempts to agitate for policy reforms and execute famine relief such as shown by English scholar William Digby. But the attempt was futile since it was intervened by the Governor of the East India Company at the time, General Lord Lytton. As a façade, Lord Lytton set up Famine Insurance Grant which was supposed to fund famine relief work. However, the fund was redirected away from the famine relief work and was used to fund other wars (Meena, 2015)

At the latter stage of the famine, the British colonial government finally acknowledges and formed the Indian Famine Commission (1880). This commission drafts the Indian Famine Code which is a guideline on responding to signs of famine. This Famine Code were passed for legislation at 1883 by Lord Rippon. Although it was late in implementation, the code managed to apply and distribute relief works to potential famine sections of the population. This Famine Code was adapted by the independent India and renamed as Scarcity Manuals (Meena, 2015). Although the famine had been amended, but we can say that the famine is largely due to misdirection of fund. In this case, the relief funds for famine were re-distributed for conquest fund.

North Korea

The Democratic People's Republic of Korea (DPRK) or as the world calls "North Korea" was a country that depends on its communist allies for aid. However, as the Cold War ends and the dissolve of the Soviet Union, the DPRK agriculture activities dwindle. This 
is because at the time during the Soviet dissolution, DPRK still depends on imports of energy and fertilizer. This long period of scarcity were further debilitate when drought struck in 1995 , where an estimated $10 \%$ percent of the population died (Leathers. \& Foster., 2010) and those whose survive suffer chronic malnutrition (Schwekendiek, 2008).

Prior to the drought calamity, the farmers receive sufficient grain rations from their harvest. However, as the yields began to fall, the farmer rations were cut. The DPRK government resolves to this action because they wanted to fulfill the quota of its food exportation (Natsios, 1999). The food export trading with China, Japan, Russia and Germany were one of the main sources of income for the DPRK government. However, as the United States put DPRK into economic embargo, the incoming aid diminished and this elevate the stressed to produce more agriculture exports. Foreign nations can only speculates on what really happened inside DPRK as foreign dignitaries and observers were not allowed to visit affected DPRK countryside (Noland, Robinson, \& Wang, 2000). This famine case is due to severe dependency to exports and imports.

From these reviews of famine cases, one can argue that these famines do not correspond to current and ongoing food policies. They can also argue that these atrocities were conducted by people of the past and not necessarily correspond to the present civilization. However, these reviews enable us to observe the trends of failed policies, and quite alarmingly, such trend is still implemented in current food policies globally.

\section{Themes and analysis of current food policies (or international policy guidelines)}


Each nation has their specific food policies to ensure food security in their countries. However, regardless of variations, most of them have similar themes; green revolution, sustainable intensification, dependency on importation, and nutritional and well-being. These themes are actually advance and reiteration version of the food policies in the past, including during the famine cases. The similarities came in the forms of market activity (role of export and import in nation's income and supply) and agricultural activities output capabilities. These 2 trends were implemented during the famine cases (although with apparent mismanagement) and are still employed in current policy with changes in terms of improved tools and sincere management.

\section{Green Revolution}

Green Revolution refer to the utilization of modern crop varieties at tropical and subtropical regions (Evenson \& Gollin, 2003). The aim of the revolution is to respond to the threat of famine and the "triple-burden" of malnutrition, which are micronutrient deficiencies, overweight and obesity (Gómez et al., 2013) It began during the late 1950's and succeeded in increasing crop production worldwide with the exception of certain countries (Evenson \& Gollin, 2003)

The theme of Green Revolution which is a focus of policy toward agriculture activities is adopted by many countries. Note that, not every country in the world involves with the Green Revolution spur by Norman Borlaug, but almost every nation had included the 
theme into their food policy. However as time passes, the crop production reach surplus. The surplus is used as trading goods and brings income to the nation. From this trend the commercial food value chains (FVC) emerges and become the main focus of food policy in recent times (Pinstrup - Andersen, 2007). The emergence of FVC will affect other aspect of food policy and this will be discussed later in this paper.

The Green Revolution does bring prosperity and advancement. Green revolution technology adoption by many countries do promote collaborative effort in improving crop genetic and agricultural technology (Pingali, 2012). The research conducted had saved millions of hectares from becoming agricultural land (Stevenson, Villoria, Byerlee, Kelley, \& Maredia, 2013). This enable more land be used for urban development and other economic activity.

However, the adoptions of Green Revolution dogma in food policy also produce unintended result. A study about the efficiency of agriculture post Green Revolution in India founds out that at the latter stage of the revolution, only farmers with larger capital fund can prolonged their success in cultivating crops (Ray \& Ghose, 2014). The success of Green Revolution in increasing crop production inadvertently stress food and crop production even beyond sustainable means. Furthermore, there were no direct correlation between improved crop productivity and reduced malnutrition in population (Gómez et al., 2013). This is discussed in next theme; Sustainable Intensification.

\section{Sustainable Intensification}


Intensification in agriculture refers to a practice where a farm is specialize to produce food in one area only; one type of livestock such as chicken or one type of crops such as corns. Since these farm focus only on one thing, the operation is conducted on an enormous scale (Lymbery, 2014; Robert Kenner, 2008). The huge operation led to addition of a suffix "mega" in front of the intensification operation such as mega-piggeries and mega-dairies. Intensification is a major agricultural practice in United States and soon will sweep across Europe and United Kingdom (Lymbery, 2014).

There are many literature that describe the negative aspect of intensification (Fukuoka \& Korn, 2009; Guerrero et al., 2012; Jones et al., 2013; Lawrence, Richards, \& Lyons, 2013), but most notably are from the award winning documentary, Food Inc. (Robert Kenner, 2008). The documentary explores the operation (although not to full extend) of corporate farming (another term for farming intensification) in the United States. It describes the absence of transparency among food corporations in disclosing their food materials and processing operations. The documentary also provides an alternative path toward transparent food production which exhibit a healthier choice. However, even the farmer that practice the healthier farming operation explain that he cannot scale-up the operations to a higher level without jeopardizing his farming operation integrity (Robert Kenner, 2008).

From the terrible outlook, comes a new evolving concept called sustainable intensification. The sustainable intensification concept incorporate changes on 
intensification practices in reducing environmental impact and increasing food production through yield (Garnett et al., 2013). However, it is too much for a goal that does not specify any methods. In reality, to achieve these goals are the gold standard of the food industry. The present intensification operation aims to produce food at lower cost. However, the operations are strife with inefficient uses and over consumption of limited resources. In doing so, they compromise environmental protection, human health and even ethical standard (Carolan, 2013).

This does not mean that intensification operation does not achieve its true goal. It does and it continues do so with improve yield when new technology and new public scheme introduce to the people.System of Rice Intensification (SRI) is a known intensification practice. In Timor Leste, System of Rice intensification was applied and it does increase the yield of under-performed farmers (Noltze, Schwarze, \& Qaim, 2012). The practice had also been a success in improving rice crop yield in Afghanistan (Thomas \& Ramzi, 2011) and Mali (Styger et al., 2011) as well as saving water irrigation (Jung, Park, Kim, \& Park, 2014) In United Kingdom, the farms were able to increase their food production and enhance the quality of the surrounding environment; achieving sustainable intensification objective. They manage to do so by applying good farming practices and management, installation of solar panels, reducing dependency on fertilizers (Firbank, Elliott, Drake, Cao, \& Gooday, 2013).

However, another question arose regarding the product of intensification, specifically the food supply. In Australia, the present policy there promotes intensification (sheep, beef 
and wheat) due to foreign direct investment (Lawrence et al., 2013). But since the products will be returned to investor nation (exportation) and most probably not entering open market, this will lead to increase of food price in the producer country. If this continue to prolong, it will lead to food crisis (Lawrence et al., 2013). This trend is eerily similar in many countries where not all foreign direct investment is beneficial to the country receiving the investment (Alias, Radam, Fen, Yacob, \& Alam, 2014; Du, Harrison, \& Jefferson, 2012; Mihalache - O’ keef \& Li, 2011; Sauer \& Pereira Leite, 2012) This perspective will be an echo on the next theme: Dependency on Importation.

\section{Dependency on Importation}

Due to rising competitiveness of global trading, certain countries forge bilateral trading relationship among them to secure flow of income. This bilateral relationship also comes in forms of receiving imports and delivering exports. Therefore, when certain crises arise, for example a country is short on funds, their exportation activities increases. When exportation taken priority over feeding, this lead to domestic food problem. This is the case of famine in North Korea (Schwekendiek, 2008) and Ukraine (Bilinsky, 1999). The North Korea is forced to produce nation income via selling the food for its people. The Ukraine peasants were forced to submit their food supply to the Soviet in order to meet their agricultural tax quota. The reverse relationship could also occur; where a nation lessens effort in producing of certain type of food coincide with prolonged increase demand depends on imports in order to balance the economy. 
The reality of this situation is that, all nations are partly involved in this web of food imports. They mostly claimed that this is part of food security strategy (Rosen, Meade, Fuglie, \& Rada, 2012). However, is the objectives really are for accommodating food demands or is it redirection of effort toward trading activities? This is describe as food system revolution by Reardon and Timmer (2012), where the food market (including food imports) slowly transition from direct sales (producer-consumer) to dependency to FVC where supermarket, fast-food chains and logistic companies delivers the food to consumer (chains of intermediary). This process lengthening the supply chain are affecting the nation economy (Reardon \& Timmer, 2012) and redirecting the efforts away from agricultural and food production activities.

There are limited literature regarding the issue, but this trend most certainly affects every countries. One country that facing the issue is Iran. Since the economic pressure imposed by the United States, the oil exports of Iran decline. This Iranian government loses 50-60 $\%$ of its revenues (Monshipouri \& Dorraj, 2013) and this severely affect the income of all income groups of household (Farzanegan, Mohammadikhabbazan, \& Sadeghi, 2015). Since Iran rely on imports for foods and goods, the government commence oil barter with goods from major importers from China and India (Monshipouri \& Dorraj, 2013). However, there are countries that try to develop counter measure against it. In Japan, they adopt protectionism, where local food producers are ensured a place in the market over foreign producers (Barclay \& Epstein, 2013). This happen because the policy makers realize the capabilities of their workforce and geographical opportunity in sustaining 
themselves. They have made this their top priority when developing their food policy (Goda, 2008).

There are countries that benefit from this trading oriented food policy. In Malaysia, cattlecrop plantations integrated production system (CCPIS) was made a scheme by Federal Land Development Authority (FELDA) and was applied by settlers or farmers (Dahlan Ismail \& Kamal Hisyam Abdul Wahab, 2014). The scheme was profitable as it increase the yield and crop produce; increasing the participant's income. The participation was overwhelming where it increase up to $150 \%$ over a period of 24 years (Dahlan Ismail \& Kamal Hisyam Abdul Wahab, 2014). The increase of food production certainly coincide with the increasing Malaysia export market over 13 years (Alias et al., 2014). However, due to international demands, Malaysia may be required (through policy) to increase its palm oil productivity (Alias et al., 2014; Ashnani, Johari, Hashim, \& Hasani, 2014). This mostly benefit the trading activity aspect of Malaysia but this raise questions regarding its contribution toward food production activities in Malaysia. This is an evidence of redirection of effort toward money-making instead of food production.

However, all of this trading activities do not accommodate the nutritional aspect of food. This is because most of these food trading involve processed food which is not necessarily healthy (Monteiro, Moubarac, Cannon, Ng, \& Popkin, 2013). This issue is explained in the next food policy trend: Nutrition and Well-being.

Nutrition and Well-being 
With the rising of imported and cheap food, comes an inquiry about their nutritional benefits. As argue by Michael Carolan (2013), the food produce by present food policies are nothing but Calorie-rization; food are reduce to energy with no nutritional value. This is not to say calorie is unimportant, but it was over utilized. Calories are use as a measurement tool for nutrition, but "it become a single variable upon which all food is to be measured" (Carolan, 2013), regardless of other nutrients. Carolan refer this to a dogma known as "nutritionism" where the value of the food is identify via "quantitative logic" using a value (in this context, calories) regardless of other factors (Scrinis, 2008). It is a fact that the current food policies produce much food and able to sell at affordable price, but this also result in global pandemic call obesity (Popkin, Adair, \& Ng, 2012) as well hidden hunger (Carolan, 2013; Robert Kenner, 2008) since all the food produce are only energy-dense food with no nutritional benefits (Monteiro et al., 2013).

There are tools developed to combat the global malnutrition problem, such as the NOURISHING framework; which is employed by Bellagio countries (Hawkes, Jewell, \& Allen, 2013). The NOURISHING framework is a package of policy area that serve as a guideline for policymaker to use (Table 1.). Therefore, it is a tool for benchmarking progress and patching the gap in each participated nation food policy. There are also calls and suggestion for reforms to include policy that incorporate healthy and nutritional based value from food production and education (Fanzo, 2014; Horlings \& Marsden, 2011; Pingali, 2012; van Dijk \& Meijerink, 2014). 
Table 1. The NOURISHING framework.

\begin{tabular}{|c|c|c|}
\hline Domain & & Policy Area \\
\hline \multirow[t]{6}{*}{$\begin{array}{c}\text { Food } \\
\text { Environment }\end{array}$} & $\mathrm{N}$ & $\begin{array}{l}\text { Nutrition label standards and regulations on the use of claims } \\
\text { and implied claims on foods }\end{array}$ \\
\hline & $\mathrm{O}$ & $\begin{array}{l}\text { Offer healthy foods and set standards in public institutions } \\
\text { and other specific settings }\end{array}$ \\
\hline & $\mathrm{U}$ & $\begin{array}{l}\text { Use economic tools to address food affordability and } \\
\text { purchase incentives }\end{array}$ \\
\hline & $\mathrm{R}$ & $\begin{array}{l}\text { Restrict food advertising and other forms of commercial } \\
\text { promotion }\end{array}$ \\
\hline & I & Improve the quality of the food supply \\
\hline & S & Set incentives and rules to create a healthy retail environment \\
\hline Food System & $\mathrm{H}$ & $\begin{array}{l}\text { Harness supply chain and actions across sectors to ensure } \\
\text { coherence with health }\end{array}$ \\
\hline \multirow{3}{*}{$\begin{array}{c}\text { Behaviour } \\
\text { Change } \\
\text { Communication }\end{array}$} & I & $\begin{array}{l}\text { Inform people about food and nutrition through public } \\
\text { awareness }\end{array}$ \\
\hline & $\mathrm{N}$ & Nutrition advice and counselling in health care settings \\
\hline & G & Give nutrition education and skills \\
\hline
\end{tabular}

Adapted from Hawkes (2013)

However, all of this could be compromise if the current policy still priorities economic and trading activities over agricultural and food production. This can be seen via the marketing of food in the market. Foods are labelled with their ingredients and health claims, but most of this information is worthless since most of the populations are not informed of actual nutrient and their functionality. Instead, they followed the blind guide of calorie value and occasional health claim of only one or two nutrients (Carolan, 2013; Scrinis, 2008). This is unethical but acceptable practice of food marketing. This does not go unnoticed but the food industry manage to put the blame into the public, not themselves (Robert Kenner, 2008). 
Fortunately, this (mal)-practice can be reduced with the guidelines of Global Hunger Index (GHI) which is published annually. GHI is a multidimensional statistical analysis that uses data from three indicators, namely: the proportion of the undernourished as a percentage of the population; the prevalence of underweight children under the age of five; and the mortality rate of children under the age of five. The report also describes each countries progress on their GHI. Therefore it is best that every policy maker consult the GHI report. The last 5 years of GHI report seems to encourage policymakers to prioritize nutrition more over trading activities.

Global Hunger Index (GHI)

GHI measurements are based on a 100-point scale, with 0 as the ideal (no hunger) and 100 being the worst. From the scale, range from 20.0 to 29.9 is termed "alarming" and a range above 30.0 is termed "extremely alarming". The measurement is based on data collected by International agencies, such as Food and Agriculture Organization of the United Nation (FAO), World Bank, World Health Organization (WHO) and United Nation children Fund (UNICEF). From the data collected, they managed to measure the GHI of 120 developing countries. Based on the last 5 years, (2010 -2014) most countries have decrease their GHI number, however there are countries that still have hunger condition at "alarming" and "extremely alarming". Table 2 lists the countries that are classified as "extremely alarming" during the last 5 years. 
Table 2. List of countries in "extremely alarming" from GHI 2010-2014

\begin{tabular}{cccccc}
\hline GHI & 2010 & 2011 & 2012 & 2013 & 2014 \\
\hline Eritrea & 35.7 & 33.9 & 34.4 & 35.0 & 33.8 \\
Burundi & 38.3 & 37.9 & 37.1 & 38.8 & 35.6 \\
Haiti & 28.0 & 28.2 & 30.8 & 23.3 & 23.0 \\
Ethiopia & 29.8 & 28.7 & 28.7 & 25.7 & 24.4 \\
Chad & 30.9 & 30.6 & 28.3 & 26.9 & 24.9 \\
Timor-Leste & 25.6 & 27.1 & 27.3 & 29.6 & 29.8 \\
Comoros & 27.9 & 26.2 & 25.8 & 33.6 & 29.5 \\
\hline
\end{tabular}

There are countries omitted, due to insufficient data throughout 2010-2014 (von Grebmer et al., 2013; von Grebmer et al., 2012; von Grebmer et al., 2010; von Grebmer et al., 2014; von Grebmer et al., 2011)

Each year, the GHI reports the ranking and provided suitable actions that can be done to lower the GHI scores. They do comparison of the current GHI scores with past GHI scores (von Grebmer et al., 2014). They also include recommended policy actions and examples from Welthungerhilfe's and Concern Worldwide organization exemplary actions (von Grebmer et al., 2010; von Grebmer et al., 2014). The recommended policy of GHI changes accordingly to the themes of the year.

GHI 2010 theme is on early childhood under nutrition. During the time, child under nutrition had reached epidemic proportions. However, the undernutrition is only concentrated in few countries and regions. Beside strengthening community, GHI also recommends policymaker to prioritize nutrition, target nutrition intervention, identify sources of under nutrition and foster gender equity (von Grebmer et al., 2010). The GHI for the year 2011 theme is rising and volatile prices. The 2011 report explains that biofuels demands coincide with rising oil price are causing rising prices of food. Other factors include climate change and the effect of speculating in future trading of agricultural 
commodities. The report recommends policymaker to reduce price spike via regulate financial activity in food market, revising biofuel policies, and climate change adaptation (von Grebmer et al., 2011).

In the following year, GHI 2012 theme is "Ensuring sustainable food security under land, water and energy stresses". Besides the demographic behavior change as a factor, the report also lists the dependency of non-renewable source and bad policies and weak institutions as factors. They recommend more efficient management in handling resources, increase education and climate change adaptation and mitigation (von Grebmer et al., 2012). "Building resilience to achieve food and nutrition security" is the theme of GHI 2013. That year, many countries had increased their GHI due to human conflict and natural calamities. Therefore, they called for conceptualization of development aid with the goal of building and strengthen the receiver resilience of the receiver from these shocks. They present coping strategies and policy actions that based on three capacity; absorptive, adaptive and transformative (von Grebmer et al., 2013).

The 2014 GHI revisited the GHI 2010 theme; "hidden hunger". The report focuses micronutrient deficiencies and presents the facts of hidden hunger throughout the world, including in developed countries. They call for integrative approach in policy making that link human capacity, agriculture and nutrition (von Grebmer et al., 2014). Based on the review of data of GHI 2010 and GHI 2014, we can assume that the theoretical productivity of the countries food policies does not translate well into actual productivity. Therefore, there must be some gap in food policy that is critically undermined. 


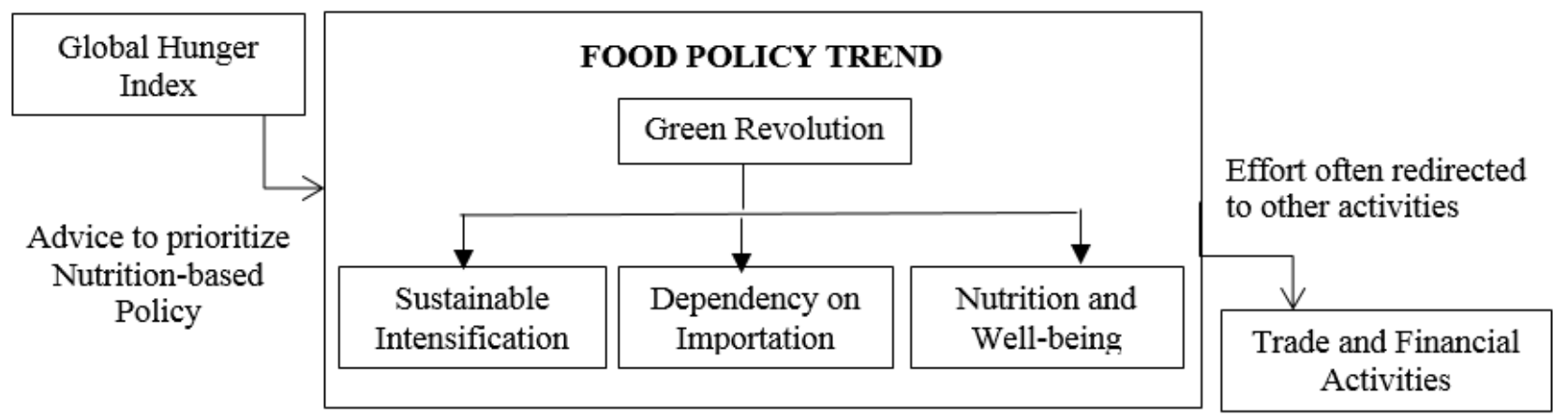

Figure 1. Trends of Food Policies

Figure 1 summarizes the themes and analysis of current food policies. The current food policies still follow the green revolutions which prioritize ineffective agricultural actions. This implication leads to sustainable intensification. Since intensification focuses on only one crop, this lead the country to depend on imports for food varieties and exports for country income. This prolonged practice led to degeneration of nutrient in food. GHI is a reference for policy maker to prioritize food and nutrition. However, the policies still prioritize trade and financial activities.

We can identify the gap based on the visitation of GHI theme which is nutrient. Beside GHI, there are many other policies that suggest the same (Abuduxike, 2014; Fanzo, 2014; Hawkes et al., 2013; von Grebmer et al., 2010; von Grebmer et al., 2014). Therefore, a more different approach is required. One sector in food policy is often not fully utilized, and that is food technology. Of course, it was often included in various food policies, but it was seldom a directive or focus action. This leads to redirection of effort of food technology towards entrepreneurship, where the local and poor develop their food product 
business with the goal of maximizing profit regardless of quality. After that, the business scale-up and becomes more of a trading company instead of a Food Company.

Because of this direction, there is lacking of food variety relative to the present scientific research. There are numerous food prototype and concept stored within intellectual property center and universities. However, they are not being commercialized due to lack of support from policy level. The policy always incentivizes common but profitable action. However, it does not incentivize people who are willing to pursue new opportunity.

\section{Food technology advancement and opportunity}

There are many exciting development in food technology research at the turning of the $21^{\text {st }}$ century. There are researches being done to emulate foreign food using substituted local resources. In Malaysia, the food researchers there had developed Mozzarella cheese substitute from palm oil (Karimah, Aminah, \& Ayob, 2001). Palm oil milk, a derivative product from palm oil had also been utilized to developed a prototype yogurt (Hadi Akbar Dahlan, Abdullah Sani, \& Dahlan, 2017). These researches utilize local resources to emulate a foreign delicacy. Besides foreign cheese, the local researchers had developed an optimized coconut yogurt, replacing the need for raw dairy materials (Yaakob Harisun, Ahmed Nor Rashidah, Daud Siti Khairunnisa, Malek Roslinda Abd, \& Rahman Roshanida Abdul, 2012). Similarly, yogurt from Tigernut (Cyperus esculentus) and African coconut had also been developed (Akoma, Elekwa, Afodunrinbi, \& Onyeukwu, 2000) 
Besides emulated carbohydrate-based food, there are also meat analogue being commercialize and further developed using local, inexpensive resources. In Indonesia, they are developing a high fiber artificial meat using local Oyster Mushroom and Gluten (Wardani \& Widjanarko, 2014). This is a good addition to accepted European meat substitutes which are usually made from soy protein, wheat protein and even mycoprotein (Hoek, Luning, Stafleu, \& de Graaf, 2004). There are also research strategies on developing meat from stem cells (Post, 2012). Although the tissue engineering method is viable for producing food-grade product (Nieuwland et al., 2014), artificial meat from stem cell had not yet been realized. Nevertheless, all of these research will provide a path for alternative livestock in food industry and hopefully support the global meat demand for the coming future.

There are also researches being done to provide ample supply of raw material and nutraceuticals using substituted local resources. In Philippines, rice from corn are being commercialized late 2014 (Philippine Leading Infinite Logistics Inc, 2014). The corn rice is able to emulate the textural and functional properties of original rice. This development will surely ensure the rice supply in Philippines. Besides rice, lactic acid bacteria are also being utilized in biorefineries to provide raw material for polymer industries (Mazzoli, Bosco, Mizrahi, Bayer, \& Pessione, 2014), nutraceutical ingredients such as amino acid enrichment ingredients (Mutaguchi, Ohmori, Akano, Doi, \& Ohshima, 2013; Ng'ong'ola - Manani, Østlie, Mwangwela, \& Wicklund, 2014) and natural texturizer (Broadbent, McMahon, Welker, Oberg, \& Moineau, 2003; Patel \& Prajapati, 2013) 
Research on food utilization also includes research on utilization of waste and unconventional materials. Apple postharvest peel waste had been utilized to become flour substitute (Jun, Bae, Lee, \& Lee, 2013). From their research, the flour substitute is able to reduce glycemic index. Besides fruit harvest, broken rice had also been modified and utilized to become fat substitute in sausage (Limberger et al., 2011). The researcher suggests that the modified broken rice can become a great fat substitute without significantly deviate the texture and sensory qualities of the sausage. Novelty artificial meat from fibrils via electrospinning had also been developed (Nieuwland et al., 2014). Although still at infancy stage, the researchers suggest gelatin as a suitable food-grade material to be produce via electrospinning.

Majority of these researches are funded via government and private grants. This can be seen via grant acknowledgement at the end of the literature. However, a more direct support from policy level is required to deliver these food innovations to the people. The aid can come in the form of incentives for technopreneurs that commercialize intellectual properties or even aid in marketing the product publicly. The policy could also require food companies to accept and commercialized local intellectual properties that are align to their food products. Also, policy can incentivize academics and researchers via the number of intellectual properties developed and commercialized. Another suggestion is to allocate fund for researching specifically in a new frontier. The fund can be collected from tax or even from industry endowment fund. 
At the very least, the policy must facilitate interaction between local resource manager and food researchers. The interaction will enable food researcher to know which part of raw or process material that is underutilized. In this case, a more effective research can be done. With the introduction of novelty product to the market, the public will gain interest in these technologies. Surely, the public will come to accept new novelty food products and these will result in 1) lessening the burden of major food producers and 2) increase innovation and productivity in terms of resource utilization for food production. The development of new novelty food products could also lead to new area of potential utilization (Dahlan, 2019). Figure 2 illustrates the actions and benefits of food policy focusing in food technology.

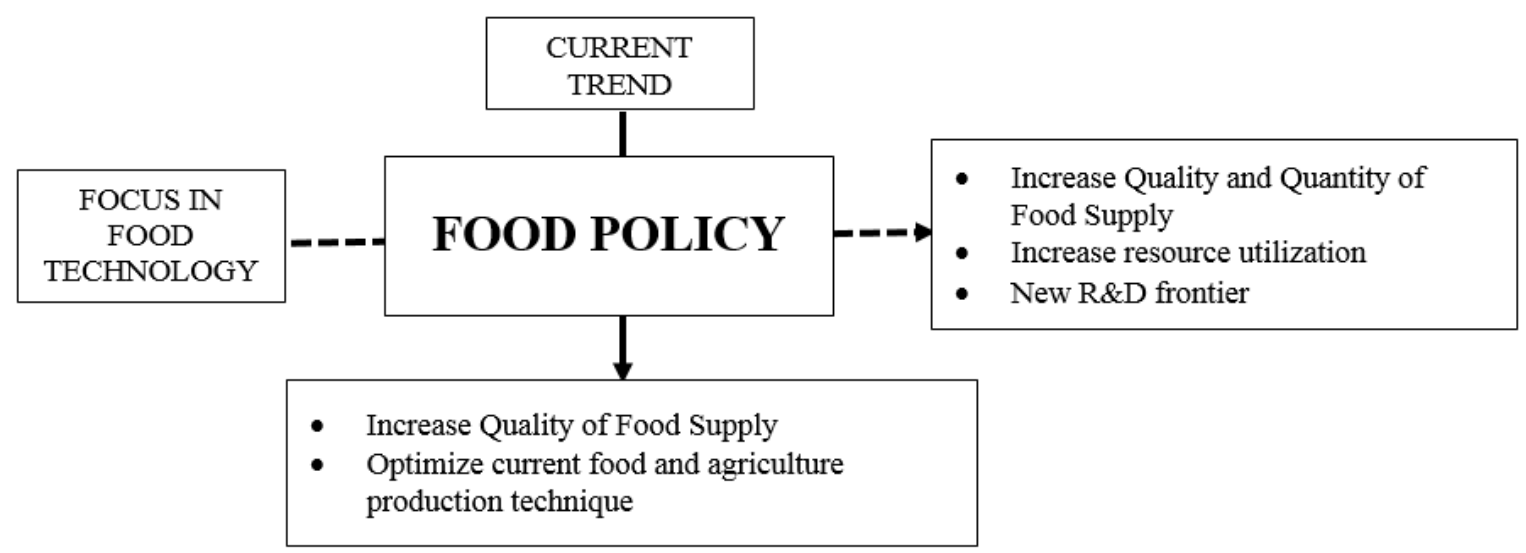

Figure 2. Action and benefits of focusing food technology in policy

\section{Conclusion}

The current food policy alone is not enough to feed the world. This is because the mechanism of feeding the world still maintain similarity with mechanisms during the past famine times. This paper has also summarized several novelty of food technology that had been utilizing waste and unconventional material in producing food. The utilization 
of new and renewable source is part of the solution in feeding the world. If the global food policy demands the food technological innovation, opportunity and knowledge will surely arise and the world should be a better place.

\section{References}

Abuduxike, G. (2014). Health biotechnology development in Malaysia: targeting local and global health needs through health technology. BMC Public Health, 14(Suppl 1), O23.

Akoma, Elekwa, Afodunrinbi, \& Onyeukwu. (2000). Yogurt from Coconut and Tigernuts. Journal of Food Technology in Africa, Vol 5(4), 132-134.

Alias, E. F., Radam, A., Fen, Y. P., Yacob, M. R., \& Alam, M. F. (2014). Growth in Malaysia's Export Food Market: A Shift-Share Analysis. Asian Social Science, 10(3), p26.

Ashnani, M. H. M., Johari, A., Hashim, H., \& Hasani, E. (2014). A source of renewable energy in Malaysia, why biodiesel? Renewable and Sustainable Energy Reviews, 35(0), 244-257. doi:http://dx.doi.org/10.1016/j.rser.2014.04.001

Barclay, K., \& Epstein, C. (2013). Securing fish for the nation: food security and governmentality in Japan. Asian Studies Review, 37(2), 215-233.

Bilinsky, Y. (1999). Was the Ukrainian famine of 1932-1933 genocide? Journal of Genocide Research, 1(2), 147-156.

Bohstedt, J. (2014). Food Riots and the Politics of Provisions in World History. IDS Working Papers, 2014(444), 1-31. doi:10.1111/j.2040-0209.2014.00444.x

Broadbent, J., McMahon, D., Welker, D., Oberg, C., \& Moineau, S. (2003). Biochemistry, Genetics, and Applications of Exopolysaccharide Production in Streptococcus thermophilus: A Review. Journal of Dairy Science, 86(2), 407-423.

Carolan, M. (2013). The real cost of cheap food: Routledge.

Dahlan, H. A. (2019). Possible Malaysian Contributions to Future Space Food during LongDuration Space Mission. ASM Science Journal, 12(Special Issue 2), 162-171.

Dahlan Ismail, \& Kamal Hisyam Abdul Wahab. (2014). Sustainability of cattle-crop plantations integrated production systems in Malaysia. International Journal of Development and Sustainability. 
Du, L., Harrison, A., \& Jefferson, G. H. (2012). Testing for horizontal and vertical foreign investment spillovers in China, 1998-2007. Journal of Asian Economics, 23(3), 234-243.

Evenson, R. E., \& Gollin, D. (2003). Assessing the impact of the Green Revolution, 1960 to 2000. Science, 300(5620), 758-762.

Fanzo, J. (2014). Strengthening the engagement of food and health systems to improve nutrition security: Synthesis and overview of approaches to address malnutrition. Global Food Security, 3(3-4), 183-192. doi:http://dx.doi.org/10.1016/j.gfs.2014.09.001

Farzanegan, M. R., Mohammadikhabbazan, M., \& Sadeghi, H. (2015). Effect of oil sanctions on the macroeconomic and household welfare in Iran: New evidence from a CGE model. Retrieved from

Firbank, L., Elliott, J., Drake, B., Cao, Y., \& Gooday, R. (2013). Evidence of sustainable intensification among British farms. Agriculture, Ecosystems \& Environment, 173, 58-65.

Fotheringham, A. S., Kelly, M. H., \& Charlton, M. (2013). The demographic impacts of the Irish famine: towards a greater geographical understanding. Transactions of the Institute of British Geographers, 38(2), 221-237.

Fukuoka, M., \& Korn, L. (2009). The one-straw revolution: an introduction to natural farming: New York Review of Books.

Garnett, T., Appleby, M., Balmford, A., Bateman, I., Benton, T., Bloomer, P., . . Fraser, D. (2013). Sustainable intensification in agriculture: premises and policies. Science, 341(6141), 33-34.

Geber, J., \& Murphy, E. (2012). Scurvy in the Great Irish Famine: Evidence of vitamin C deficiency from a mid - 19th century skeletal population. American journal of physical anthropology, 148(4), 512-524.

Goda, M. (2008). Agricultural Multifunctionality and Village Viability. Multifunctionality in Agriculture, 65-72.

Gómez, M. I., Barrett, C. B., Raney, T., Pinstrup-Andersen, P., Meerman, J., Croppenstedt, A., . . . Thompson, B. (2013). Post-green revolution food systems and the triple burden of malnutrition. Food Policy, 42, 129-138.

Guerrero, I., Morales, M. B., Oñate, J. J., Geiger, F., Berendse, F., de Snoo, G., . . Clement, L. W. (2012). Response of ground-nesting farmland birds to agricultural intensification across 
Europe: landscape and field level management factors. Biological Conservation, 152, 7480.

Hadi Akbar Dahlan, Abdullah Sani, N., \& Dahlan, I. (2017). Logistic-like Growth Model of Lactobacillus acidophilus, Lactobacillus delbrueckii subsp. bulgaricus and Streptococcus thermophilus in Palm Oil Santan. 日本食品工学会誌 (Japan Journal of Food Engineering), 18(3), 155-159. doi:https://doi.org/10.11301/jsfe.16474

Hawkes, C., Jewell, J., \& Allen, K. (2013). A food policy package for healthy diets and the prevention of obesity and diet - related non - communicable diseases: the NOURISHING framework. Obesity Reviews, 14(S2), 159-168.

Headey, D. (2011). Rethinking the global food crisis: The role of trade shocks. Food Policy, 36(2), 136-146.

Hoek, A. C., Luning, P. A., Stafleu, A., \& de Graaf, C. (2004). Food-related lifestyle and health attitudes of Dutch vegetarians, non-vegetarian consumers of meat substitutes, and meat consumers. Appetite, 42(3), 265-272.

Horlings, L., \& Marsden, T. (2011). Towards the real green revolution? Exploring the conceptual dimensions of a new ecological modernisation of agriculture that could 'feed the world'. Global environmental change, 21(2), 441-452.

Ian, M. (2013). The Chemistry of Famine: Nutritional Controversies and the Irish Famine c. 18457'. Medical History, 56(4), 444-462.

Ibrahim, M. H. (2015). Oil and food prices in Malaysia: a nonlinear ARDL analysis. Agricultural and Food Economics, 3(1), 1-14.

Jones, B. A., Grace, D., Kock, R., Alonso, S., Rushton, J., Said, M. Y., . . McDermott, J. (2013). Zoonosis emergence linked to agricultural intensification and environmental change. Proceedings of the National Academy of Sciences, 110(21), 8399-8404.

Jun, Y., Bae, I. Y., Lee, S., \& Lee, H. G. (2013). Utilisation of preharvest dropped apple peels as a flour substitute for a lower glycaemic index and higher fibre cake. International journal of food sciences and nutrition, 65(1), 62-68.

Jung, C.-G., Park, J.-Y., Kim, S.-J., \& Park, G.-A. (2014). The SRI (system of rice intensification) water management evaluation by SWAPP (SWAT-APEX Program) modeling in an agricultural watershed of South Korea. Paddy and Water Environment, 12(1), 251-261. 
Karimah, A., Aminah, A., \& Ayob, M. K. (2001). Potential of palm blend in the formulation of mozzarella analogue. Palm Oil Devel, 35, 1-7.

Kinealy, C. (2001). The great Irish famine: impact, ideology and rebellion: Palgrave Macmillan.

Lawrence, G., Richards, C., \& Lyons, K. (2013). Food security in Australia in an era of neoliberalism, productivism and climate change. Journal of Rural Studies, 29, 30-39.

Leathers., H. D., \& Foster., P. (2010). The world food problem: toward ending undernutrition in the third world (4th ed.). Colorado: Lynne Rienner Publishers.

Levinson, F. J. (1974). Morinda: an economic analysis of malnutrition among young children in rural India. MA: Cornell/MIT International

Limberger, V. M., Brum, F. B., Patias, L. D., Daniel, A. P., Comarela, C. G., Emanuelli, T., \& Silva, L. P. d. (2011). Modified broken rice starch as fat substitute in sausages. Food Science and Technology (Campinas), 31(3), 789-792.

Lymbery, P. (2014). Farmageddon: the true cost of cheap meat: Bloomsbury Publishing.

Maxwell, S., \& Slater, R. (2003). Food Policy Old and New. Development Policy Review, 21(56), 531-553.

Mazzoli, R., Bosco, F., Mizrahi, I., Bayer, E. A., \& Pessione, E. (2014). Towards lactic acid bacteria-based biorefineries. Biotechnology Advances, 32(7), 1216-1236.

Meena, H. K. (2015). Famine in Late 19th Century India: Natural or Man-Made. Journal of Human and Social Science Research; Vol, 6(01), 035-044.

Mihalache - O’ keef, A., \& Li, Q. (2011). Modernization vs. Dependency Revisited: Effects of Foreign Direct Investment on Food Security in Less Developed Countries1. International Studies Quarterly, 55(1), 71-93.

Monshipouri, M., \& Dorraj, M. (2013). Iran's Foreign Policy: A Shifting Strategic Landscape. Middle East Policy, 20(4), 133-147.

Monteiro, C. A., Moubarac, J. C., Cannon, G., Ng, S. W., \& Popkin, B. (2013). Ultra - processed products are becoming dominant in the global food system. Obesity Reviews, 14(S2), 2128.

Mutaguchi, Y., Ohmori, T., Akano, H., Doi, K., \& Ohshima, T. (2013). Distribution of D-amino acids in vinegars and involvement of lactic acid bacteria in the production of D-amino acids. SpringerPlus, 2(1), 691.

Natsios, A. S. (1999). The politics of famine in North Korea: US Institute of Peace. 
Ng'ong'ola - Manani, T. A., Østlie, H. M., Mwangwela, A. M., \& Wicklund, T. (2014). Metabolite changes during natural and lactic acid bacteria fermentations in pastes of soybeans and soybean - maize blends. Food science \& nutrition, 2(6), 768-785.

Nieuwland, M., Geerdink, P., Brier, P., van den Eijnden, P., Henket, J. T., Langelaan, M. L., . . . Martin, A. H. (2014). Reprint of" Food-grade electrospinning of proteins". Innovative Food Science \& Emerging Technologies, 24, 138-144.

Noland, M., Robinson, S., \& Wang, T. (2000). Rigorous Speculation: The Collapse and Revival of the North Korean Economy. World Development, 28(10), 1767-1787.

Noltze, M., Schwarze, S., \& Qaim, M. (2012). Farm Diversity and Heterogeneous Impacts of System Technologies on Yield, Income and Poverty: The System of Rice Intensification in Timor Leste. Paper presented at the 2012 Conference, August 18-24, 2012, Foz do Iguacu, Brazil.

Patel, A., \& Prajapati, J. (2013). Food and health applications of exopolysaccharides produced by lactic acid bacteria. Adv Dairy Res, 1(107), 2.

Philippine Leading Infinite Logistics Inc. (2014). yummy Healthy Life. Retrieved from http://yummyhealthy.ph/

Pingali, P. L. (2012). Green Revolution: Impacts, limits, and the path ahead. Proceedings of the National Academy of Sciences, 109(31), 12302-12308.

Pinstrup - Andersen, P. (2007). Agricultural research and policy for better health and nutrition in developing countries: a food systems approach. Agricultural Economics, 37(s1), 187-198.

Popkin, B. M., Adair, L. S., \& Ng, S. W. (2012). Global nutrition transition and the pandemic of obesity in developing countries. Nutrition reviews, 70(1), 3-21.

Post, M. J. (2012). Cultured meat from stem cells: Challenges and prospects. Meat Sci, 92(3), 297301.

Ray, S. C., \& Ghose, A. (2014). Production efficiency in Indian agriculture: An assessment of the post green revolution years. Omega, 44, 58-69.

Reardon, T., \& Timmer, C. P. (2012). The economics of the food system revolution. Annu. Rev. Resour. Econ., 4(1), 225-264.

Robert Kenner. (2008). Food Inc. (pp. 94 minutes). USA: Magnolia Pictures.

Rosen, S., Meade, B., Fuglie, K., \& Rada, N. (2012). International Food Security Assessment, 2014-2024. Economic Research, 2014, 2024. 
Sauer, S., \& Pereira Leite, S. (2012). Agrarian structure, foreign investment in land, and land prices in Brazil. Journal of Peasant Studies, 39(3-4), 873-898.

Schwekendiek, D. (2008). The North Korean standard of living during the famine. Social Science \& Medicine, 66(3), 596-608. doi:http://dx.doi.org/10.1016/j.socscimed.2007.09.018

Scrinis, G. (2008). On the ideology of nutritionism. Gastronomica, 8(1), 38-48.

Spedding, C. R. W. (1979). An introduction to agricultural systems: Applied Science Publishers.

Stevenson, J. R., Villoria, N., Byerlee, D., Kelley, T., \& Maredia, M. (2013). Green Revolution research saved an estimated 18 to 27 million hectares from being brought into agricultural production. Proceedings of the National Academy of Sciences, 110(21), 8363-8368.

Styger, E., Attaher, M. A., Guindo, H., Ibrahim, H., Diaty, M., Abba, I., \& Traore, M. (2011). Application of system of rice intensification practices in the arid environment of the Timbuktu region in Mali. Paddy and Water Environment, 9(1), 137-144.

Thomas, V., \& Ramzi, A. M. (2011). SRI contributions to rice production dealing with water management constraints in northeastern Afghanistan. Paddy and Water Environment, 9(1), 101-109.

Timmer, C. P., Falcon, W. P., \& Pearson, S. R. (1981). Food policy analysis (Vol. 1983): Johns Hopkins University Press Baltimore.

van Dijk, M., \& Meijerink, G. W. (2014). A review of global food security scenario and assessment studies: Results, gaps and research priorities. Global Food Security, 3(3-4), 227-238. doi:http://dx.doi.org/10.1016/j.gfs.2014.09.004

von Grebmer, K., Headey, D., Olofinbiyi, T., Wiesmann, D., Fritschel, H., Yin, S., . . Haddad, L. (2013). 2013 Global Hunger Index. Retrieved from Bonn / Washington, D.C. / Dublin:

von Grebmer, K., Ringler, C., Rosegrant, M. W., Olofinbiyi, T., Wiesmann, D., Fritschel, H., .. . Rahall, J. (2012). 2012 Global Hunger Index. Retrieved from Bonn / Washington, D.C. I Dublin:

von Grebmer, K., Ruel, M. T., Menon, P., Nestorova, B., Olofinbiyi, T., Fritschel, H., . . . Thompson, J. (2010). 2010 Global Hunger Index. Retrieved from Bonn / Washington, D.C. / Dublin:

von Grebmer, K., Saltzman, A., Birol, E., Wiesmann, D., Prasai, N., Yin, S., . . S Sonntag, A. (2014). 2014 Global Hunger Index. Retrieved from Bonn / Washington, D.C. / Dublin: 
von Grebmer, K., Torero, M., Olofinbiyi, T., Fritschel, H., Wiesmann, D., Yohannes, Y., ... von Oppeln, C. (2011). 2011 Global Hunger Index. Retrieved from Bonn / Washington, D.C. / Dublin:

Wardani, N. A. K., \& Widjanarko, S. B. (2014). Potential of Oyster Mushroon (Pleurotus ostreatus) and Gluten in the Production of Artificial Meat with High Fiber Content. Jurnal Teknologi Pertanian, 14(3).

Yaakob Harisun, Ahmed Nor Rashidah, Daud Siti Khairunnisa, Malek Roslinda Abd, \& Rahman Roshanida Abdul. (2012). Optimization of ingredient and processing levels for the production of coconut yogurt using response surface methodology. Food science and biotechnology, 21(4), 933-940. 